PREPARED IN COOPERATION WITH DEPARTMENT OF ECONOMIC DEVELOPMENT MAINE GEOLOGICAL, SURVEY

\title{
AEROMAGNETIC MAP OF THE HOULTON QUADRANGLE, AROOSTOOK COUNTY, MAINE
}

By

W.J. Dempsey

\section{GEOPHYSICAL INVESTIGATIONS \\ MAP GP- 295}

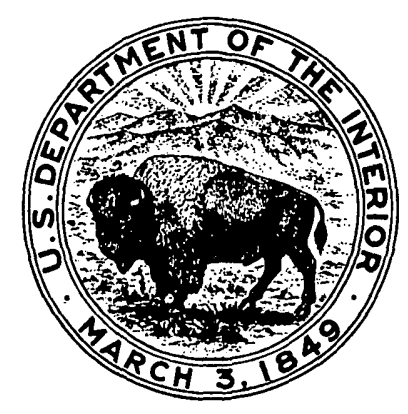

